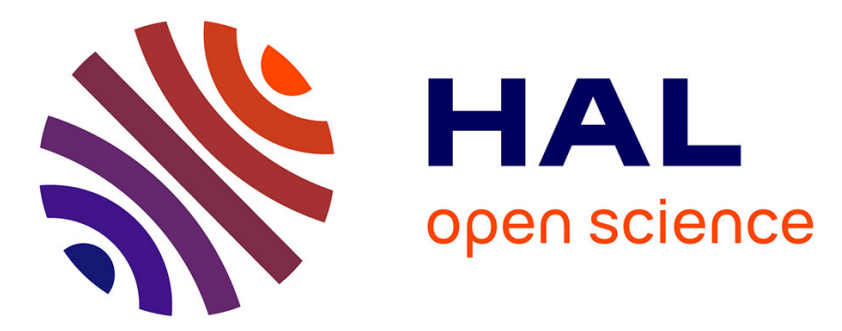

\title{
Should any new light rail line provide real estate gains, or not? The case of the T3 line in Paris
}

\author{
Francis Papon, Dany Nguyen Luong, Elise Boucq
}

\section{To cite this version:}

Francis Papon, Dany Nguyen Luong, Elise Boucq. Should any new light rail line provide real estate gains, or not? The case of the T3 line in Paris. Research in Transportation Economics, 2015, 49, pp 43-54. 10.1016/j.retrec.2015.04.005 . hal-01216343

\section{HAL Id: hal-01216343 \\ https://hal.science/hal-01216343}

Submitted on 16 Oct 2015

HAL is a multi-disciplinary open access archive for the deposit and dissemination of scientific research documents, whether they are published or not. The documents may come from teaching and research institutions in France or abroad, or from public or private research centers.
L'archive ouverte pluridisciplinaire HAL, est destinée au dépôt et à la diffusion de documents scientifiques de niveau recherche, publiés ou non, émanant des établissements d'enseignement et de recherche français ou étrangers, des laboratoires publics ou privés. 


\section{SHOULD ANY NEW LIGHT RAIL LINE PROVIDE REAL ESTATE GAINS, OR NOT? THE CASE OF THE T3 LINE IN PARIS}

Francis PAPON, Université Paris-Est (UPE), French Institute of Science and Technology for Transport, Development and Networks (IFSTTAR), Department for Planning, Mobility and Environment (AME), Director of laboratory Economic and Social Dynamics of Transport (DEST) F-77447 Marne-la-Vallée, France, francis.papon@ifsttar.fr

Dany NGUYEN-LUONG, Institute for Urban Planning and Development of Paris Île-deFrance Region (IAU), Paris, France, dany.nguyen-luong@iau-idf.fr

Elise BOUCQ, Haute Ecole Condorcet, Hainaut, Belgium, elise.boucq@condorcet.be

\section{ABSTRACT}

This paper presents a research to assess real estate gains brought by a new light rail infrastructure: the T3 tramway line in Paris opened in December 2006. Based on comprehensive geo-located data, it mainly focuses on econometric hedonic modelling where accessibility gains are included besides other intrinsic and extrinsic variables. In spite of different specifications, no model yielded any significant effect of the new line. Finally, the rationale for such an outcome is discussed, and by comparison with other studies, the factors for a new line to provide significant gains are listed.

Keywords: light rail, Paris, accessibility, hedonic models, real estate gains, land rents

\section{INTRODUCTION}

\subsection{Context}

This paper presents the outcomes of a study aimed at evaluating the impact of the T3 tramway line in Paris on housing real estate prices.

The study is part of a series of studies by IAU Ile-de-France and IFSTTAR (former INRETS) on the evaluation of real estate impacts of transport infrastructures or policies (T1 tramway line, Nguyen-Luong, 2006; T2 tramway line, Boucq \& Papon, 2007; RER E, Nguyen-Luong, 2006; Zones 30 in Paris, Glachant, Bureau \& Nguyen-Luong, 2008). On the one hand, these studies are conducted in a context where public funding is becoming scarcer and where the government is searching for new sources of public transport project funding. One possible 
source would be taxing part of real estates gains brought by new infrastructures, though it raises technical and juridical issues beyond the scope of this research. On the other hand, such studies may help at improving transport and land use models, such as SIMAURIF (De Palma \& Nguyen-Luong, 2004 à 2008), that simulates two-way effects between transport infrastructure and land use in the middle-long run, in particular households and jobs location and land and real estate rents, which include " wider benefits ", i.e. positive externalities beyond classical time gains.

The study was conducted in six phases: (1) bibliographic synthesis, (2) data collection, (3) field survey passed to real estate agents, (4) descriptive analysis, (5) estimation and validation of a hedonic regression price model, (6) summary of five studies on the real estate effects of a new transport infrastructure in lle-de-France. This paper will focus on the outcomes of the hedonic model.

\subsection{Scope and limitations}

As this paper focuses on the outcomes of the hedonic model, it will not present the results of other approaches, in particular field survey and descriptive analysis, which do forewarn the hedonic results. This paper is a case analysis, and does not aim primarily at improving theoretical modelling developments. So the lessons of this paper should be more to compare with other transport service change effects on real estate price, and draw general laws in this regard.

The main merit of this work relies on the substantial dataset that was applied. The comprehensive property transfer base makes it possible to detect the slightest effect. The most innovative part is the use of accurate dwelling location, with postal address and full geo-location, so that spatial effect can be fully captured: to the authors' knowledge, this was never used before.

The main limitation is the limited data used to compute accessibility gains: travel time changes were the outcome of modelling, and not real travel time measurements. So maybe the actual travel time savings brought by tramway T3 were lower than expected.

\section{DATA}

\subsection{The $T 3$ tramway line}

The T3 tramway line was opened to operation on December 16, 2006, replacing a former bus line. Its main characteristics are: $7.9 \mathrm{~km}$ length, 17 stations, 26 minutes travel time between terminus stations, 115,000 travellers per day on average in 2010 (double the previous bus line), 5:00 a.m. to $12: 30$ a.m. operation, $16.5 \mathrm{~km} / \mathrm{h}$ commercial speed (compared to 14.5 for the previous bus line), 7 metro lines and 37 bus lines in direct transfer, lawn grown on $70 \%$ of the lay-out.

$13^{\text {th }}$ WCTR, July 15-18, $2013-$ Rio de Janeiro, Brazil 
The study area is set $4 \mathrm{~km}$ apart both sides of the tramway line, partly covering 8 Paris arrondissements, 7 municipalities in county Hauts-de-Seine (Boulogne, Issy-les-Moulineaux, Vanves, Malakoff, Châtillon, Montrouge, Bagneux) and 5 municipalities in county Val-deMarne (Arcueil, Gentilly, Villejuif, Le Kremlin-Bicêtre, Ivry-sur-Seine), including the line corridor defined 400 meters apart both sides of the tramway line.

The T3 line was extended end of 2012 from Porte d'Ivry to Porte de la Chapelle with 25 new stations.

A recent cost-benefit analysis of the T3 tramway (Prud'homme et al., 2011) finds that the new line produced a net loss for travellers, as increase in road congestion offsets time savings to public transport users.

\subsection{Real estate data source}

The richest possible data were used for this research. All collected transaction data were geo-located at the postal address. Historically in France in this type of study, transaction data were at the municipality level, or recently at the IRIS area level (defined with population of 2000 inhabitants, T2 study by INRETS, Boucq, 2008) or at the street level (T1, RER E and Green neighbourhoods studies by IAU Ile-de-France, Nguyen-Luong, 2006). Such an accurate location allows computing precisely extrinsic variables such as distances to amenities.

This database takes into account only the properties on the transaction market (for sale). It excludes properties outside this market (for rent): council housing and privately rented flats. The database is BIEN from the Paris Notary Chamber who detains the exhaustive transaction data from 1990 to today. The great pro of this base is that all transactions are geo-located with Lambert II coordinates $X Y$ at their postal address. Seven years, from January 1, 2002 to December 31, 2008 were included, five years before tramway operation and two years after.

\subsection{Unfavourable economic trend}

An additional concern has occurred during the study, as the real estate crisis burst in 20082009. A study by the Paris Notary Chamber ${ }^{1}$ showed that the number of housing sales in the region lle-de-France plummeted by $40 \%$ in the first term of 2009 as compared to previous year. This fall concerned all housing categories: old flats $(-41 \%)$, new flats $(-46 \%)$, old houses $(-44 \%)$ and new houses (-56\%). Prices also fell in the same time, although in 2010 they recovered the previous increasing trend. Thus, for the first time since the second term of 1998 , old flats in Paris city have recorded a decrease in annual variation $(-1,0 \%$ at 6360 euros $/ \mathrm{m} 2$ vs. $+9,4 \%$ in the first term of 2008$)$. The fall is higher in inner suburbs $(-5 \%)$ and in

\footnotetext{
${ }^{1}$ Votre notaire vous informe, été 2009, available (18 August 2014) at http://www.paris.notaires.fr/sites/default/files/vnvi/votre_notaire_vous_informe_ete_2009.pdf $13^{\text {th }}$ WCTR, July 15-18, $2013-$ Rio de Janeiro, Brazil
} 
outer suburbs (-8\%). This price decrease does not ease descriptive comparisons before/after and the interpretation of the econometric analysis results.

\subsection{Real estate data 2002 to 2008}

The database on the study area includes 162,032 transactions (or sales or transfers) of flats between $01 / 01 / 2002$ and $31 / 12 / 2008$. Table 1 shows the distribution of flat transactions by year on the study area:

Table I - Number of transactions per year in the study area

\begin{tabular}{|l|l|l|l|l|l|l|l|l|}
\hline Years & 2002 & 2003 & 2004 & 2005 & 2006 & 2007 & 2008 & Total \\
\hline Number of transactions & 22468 & 22673 & 24663 & 26172 & 23851 & 23143 & 19062 & 162032 \\
\hline
\end{tabular}

The available fields are: reference number, transfer date, transfer price, municipality code, street type, street name, floor number, new or old, liveable surface area, number of rooms, lift, garage, building period (9 classes), previous transfer date, previous transfer price, $\mathrm{X}, \mathrm{Y}$.

\section{LITERATURE}

\subsection{Hedonic modelling principles}

To study the effect of a transport infrastructure on real estate prices, hedonic modelling is generally used (for example DREIF, 2002; Deymier, 2005; Boucq, 2008).

This method is particularly suited as properties are heterogeneous goods, and their price depends on their characteristics, intrinsic and extrinsic. Intrinsic characteristics are those that belong to the property itself (surface area, number of rooms, number of bathrooms...), and extrinsic characteristics are those of the environment where the property is located (sociodemographics, proximity to local public facilities such as schools and hospitals, or local transport conditions.

To measure the possible effects of the T3 tramway on real estate prices, a hedonic price model based on the founding work by Rosen (1974) is built. The hedonic function will provide an estimation of properties as a function of their characteristics.

Once this function is estimated, the fictive price of properties if the tramway had not been put in operation, and the price of properties taking into account the tramway service can be computed. The difference is the gain brought by the tramway implementation, as the hedonic function provides a measurement of one single variable modification impact on prices, everything else being equal, and enables to separate the tramway effect from other price determinants. 


\subsection{Use of hedonic models in real estate economy}

The big pro of hedonic models is their ability to separate the effects of different characteristics on housing price, making it possible to study the consequences of modifying one characteristic. The following studies can be quoted:

- Beckerich (2000) studies the effects of local public goods;

- Letombe et Zuindeau (2001) work on the impact of disused industrial estates;

- Saulnier (2004) and Brasington - Hite (2005) deal with the influence of air quality;

- Faburel et al. (2004) estimate the dwelling price depreciation due to air traffic noise near Orly airport;

- Brossard et al. (2007) assess the impact of landscape attributes on real estate prices;

- Glachant et al. (2008) measure the importance of so-called "green neighbourhoods" and "quiet neighbourhoods" policies in Paris.

Other authors evaluate as we do the consequences of some transport condition change on dwelling prices, such as for instance:

- Deymier (2005) works on the impact of the opening of Lyon north ring freeway;

- Nguyen-Luong (2006) on the impact of tramway T1 and RER E in region lle-deFrance;

- Debrezion et al. (2007) on the impact of railways in the Netherlands;

- Boucq (2008) on the impact of tramway T2 in county Hauts-de-Seine;

- Calzada and Decremer (2009) on the impact of East-European high speed rail in regions Alsace, Lorraine and Champagne-Ardenne;

- Rodríguez \& Mojica (2009) or Cervero \& Kang (2011) on the impact of BRT services.

\subsection{How do hedonic models take into account the link between transport infrastructure and real estate prices?}

There exist many empirical studies, in particular in the Anglo-Saxon literature, on the relation between transport infrastructures (road or rail) and real estate prices, mobilizing the hedonic theory. But often those studies represent this relation with the shortest distance between dwelling and infrastructure or between dwelling and the nearest station.

The following four studies, conducted in the United States in the 1990's, examine important rail transport infrastructures at the interurban scale: Gatzlaff and Smith (1993) study the impact of a new rail system METRORAIL in Miami; Armstrong (1994) in Boston; McDonald and Osuji (1995) in Chicago; Benjamin and Sirmans (1996) in Washington, DC.

In these four studies, a continuous variable, proximity from dwelling to station, is used to measure the effect of the infrastructure on prices. For that, even if it exists, the negative effect of the immediate proximity to station, as evidenced by other authors (Bowes and Ihlanfeldt (2001) or Kazmierczak and Jayet (2002)), cannot be found. Similarly, to study the impact of a road transport network change on single family housing prices, Smersh and Smith (2000) and Boarnet and Chalermpong (2001) use distance between dwelling and the 
nearest access to the studied infrastructure, in a continuous manner. However, the former study the impact of a new bridge in Jacksonville (so without necessarily a negative effect of immediate proximity to bridge). The latter, to study the impact of building a toll road network in the Orange county (California) exclude dwellings that are too close, so as to avoid negative externalities produced by the immediate vicinity to a highway.

Bowes and Ihlanfeldt (2001), when studying the impact of railroads in the Atlanta region on single family real estate prices, introduce distance between dwelling and the nearest station in a discrete form by means of four dummy variables, so as to take into account non linear impacts. Similarly, Yiu and Wong (2005) use the shortest distance between dwelling and infrastructure in a non-linear form by introducing four zone dummies, aiming at estimating the real estate price impact of building a tunnel in Hong-Kong. Besides introducing four station proximity zone dummies, Bowes et Ihlanfeldt (2001) use, to represent accessibility to jobs as in urban models, road mileage to CBD and a gravity variable for job proximity, as Gordon and Richardson (1983), Cao and Hough (2007) and Ottensmann et al. (2008), making it possible to take into account decentralization. But this effect does not come out as significant. Franklin and Waddell (2003) and Du and Mulley (2006) introduce gravity accessibility measures too, but for access to specific activities.

In their study on the impact of railway lines on real estate prices in the Netherlands, Debrezion et al. (2007) introduce three indicators to capture rail effect: distance to stations in a discontinuous form (zone dummies), train frequency and proximity of dwelling to railway line. The second indicator has a weak effect on prices, and the third one makes it possible to capture train negative externalities (mainly noise). The specificity of their study lies in the first indicator: as most authors, they construct this distance variable from dwelling to the nearest station, they construct another one by referring not to the nearest station, but to the one that is most frequently used according to zip code. With this second variable, the effect is much stronger. In fact, the most often chosen station benefits from additional features, which are not directly observable.

For France, Gravel et al. (2002) explain house transfer prices in 33 towns of county Val d'Oise, and introduce as accessibility variables the time needed to go from these 33 selected towns to Châtelet-les-Halles station (in central Paris) at peak hours by road and by transit, as well as the shortest distance between town centre and freeway entrance.

In the study by DREIF (2002) on tramway T1 Saint-Denis - Bobigny impact on land and real estate prices, the notion of accessibility to jobs is explicitly taken into account: the indicators used are the number of jobs and the number of persons accessible within 30 minutes by transit from the considered zone. But it is not so in Deymier (2005) on the effects of Lyon north ring freeway opening on real estate prices, who use as accessibility indicator the access distance to the nearest north ring access, neither in Calzada and Decremer (2009) on the impact of East European high speed rail in regions Alsace, Lorraine and ChampagneArdenne, who use as accessibility measure the travel time from each municipality to cities along the corridor. Kazmierczak and Jayet (2002), in their study of the impact of tramway T2 on real estate prices, evidence a negative effect of T2 station proximity, but a positive effect 
of average travel time savings, thence show that this infrastructure is valued not for its proximity, but for the accessibility gains provided. Boucq (2008) also study the impact of tramway T2 service in county Hauts-de-Seine on housing prices, but use potential accessibility indicators to all jobs in county Hauts-de-Seine.

Thus, the way of taking into account transport infrastructure for estimating prices is very variable across studies, and scarcely explicitly through job accessibility terms, as taught by urban economy.

\subsection{Improvement targets in this research}

One question is whether the effects of infrastructures on land and/or real estate rents are positive and significant. According to the comprehensive review by Deschamps (2008), since the 1950's, study results have been very variable. The outcomes depend on infrastructure type, distance to infrastructure, period taken into account, and urban dynamics. The author points out the following methodological flaws. The attempts of the research presented in the current paper to overcome these issues are mentioned.

- The spatial level of analysis should not be at the municipality level but more accurate to seize household preferences, distance to transport services and other amenities, and the housing micro-markets: in this research, the dwelling location is accurately determined at the postal address level, so as to compute exact distance to amenities.

- Data should be individual transactions and not aggregated: so is the BIEN database.

- Price data should be real sale prices and not the price displayed before bargaining: so is the BIEN database.

- Anticipation effects are rarely taken into account: data are recorded five year before opening to take this effect into account.

- The most important variable, accessibility, is often imperfect (often linear where a more complex form would be needed) and its parameter has decreased over time: a log-sum form is used.

- Statistical methods do not always allow accurate measurement of a very small time gain effect: unfortunately, due to the limited travel time savings provided by the T3 tramway, and the difficulty in measuring it, this remains a limitation in this study.

- Besides transport variables, two other variable types should be integrated in the price model intrinsic variables (surface area, building age, lift...) and extrinsic variables (proximity to urban amenities, neighbourhood social characteristics): so are the models in this study.

- Co-linearity and space heterogeneity between variables may induce cumulative effects that may produce counter intuitive outcomes: the most relevant space variables were selected; some do overlap, but due to the huge dataset, all yield significant and expected results.

In spite of hardly comparable studies as each case is different, and in spite of varying accessibility effects on housing prices (in nature and intensity), one consensus emerges: when transport effects are significant, they are low.

$13^{\text {th }}$ WCTR, July 15-18, $2013-$ Rio de Janeiro, Brazil 


\section{METHODOLOGY}

\subsection{Hedonic model description}

The estimated model is based on Rosen's formulation (1974):

$F(p)=X 1 \beta 1+X 2 \beta 2+\varepsilon$

With $\mathrm{p}$ housing price vector, and $\mathrm{F}($.$) hedonic function, supposed in a first step to be of the$ Box-Cox form. It is assumed that characteristics are desirable and that agents' choices obey the utility maximization principle. $X 1$ and $X 2$ are characteristics observation matrices (X1 intrinsic and $X 2$ extrinsic). $\varepsilon$ is an independent and identically distributed error term vector.

Thus each composite good basket $(\mathrm{X} 1, \mathrm{X} 2)$ corresponds to a market price $\mathrm{p}$ estimated by hedonic function $F($.$) .$

\subsection{Model variables}

According to data availability, the following fifty or so explanatory variables were tested.

A) Intrinsic characteristics: building period, liveable surface area, number of rooms, average surface area per room, floor number, lift, number of garages.

B) Transfer characteristics: current transfer year, current transfer month, previous transfer year, dummy "transfer after Olympiades station opening (June 2007)".

C) Extrinsic characteristics are sorted into 7 categories.

1) Address: municipality, arrondissement if Paris city, neighbourhood if Paris city (80 neighbourhoods), street type (14 types: avenue, boulevard etc.), orientation with respect to the T3 line (6 classes: north, south, northeast, southeast, northwest, southwest).

2) Proximity (after the land use data), i.e. distances to the nearest facility of each type: woods and forests, leisure parks, gardens and parks, habitat gardens, shopping malls, all shopping facilities, sheltered sport facilities, middle schools, high schools, higher education, hospitals, cemeteries, great cultural facilities, transport infrastructure more than 25 meters wide.

3) Dummies whether the property belongs to a particular land use polygon: single-family housing, single-family housing residence, rural housing, multi-family low-rise row-housing, multi-family high-rise row-housing, multi-family high-rise detached housing, prisons, other habitat, activities in mixed urban fabric, facilities for water, sewage, energy and industry.

4) Other proximity variables, i.e. distances to the nearest facility of each type: metro station excluding Olympiades, SNCF and RER train station, passenger railways, ZAC urban 
development zone, T3 tramway line or station, Châtelet station, gare de Lyon station, Montparnasse station, Saint-Lazare station.

5) Other dummies: property within 500 meters (respectively 200 meters, between 200 and 400 meters) from Olympiades station, address on boulevard des Maréchaux (it is not known whether the flat windows faces or not the boulevard).

6) Variables linked to INSEE blocks crossed with land use: percentage of natural area in block, percentage of industry in block, percentage of tertiary activity in block, number of jobs per block.

7) Socio-economic variables linked to IRIS population zones (INSEE): percentage of persons aged 60 and over in IRIS, percentage of couples with 3 children or more in IRIS, percentage of households by household size (1, 2, 3, 4 and over) in IRIS, percentage of households the head of which belongs to a particular socio-professional category (farmer, retailer/craftsman/business boss, executive, intermediary profession, employee, worker, retired, without professional activity) in IRIS, percentage of foreigners in IRIS population, percentage of unemployed among IRIS working population, percentage of higher education degrees in IRIS, population aged 20 and over, percentage of dwellings lacking one comfort element (WC, shower or bath, heating).

D) Accessibility variables ( $\log$ sum ») to jobs. The accessibility of one zone is the weighted sum of jobs located in all zones, weighted by a function of transport time, computed as:

$$
A_{i}=\sum_{j} E_{j} \cdot \exp \left(-\lambda \cdot T_{i j}\right)
$$

\section{Where}

Log(Ai): accessibility to jobs of zone i by public transport;

Ej: number of jobs in zone j (source: regional job survey ERE 2001);

Tij: public transport travel time between i and $\mathrm{j}$ (source: STIF);

$\lambda$ : parameter (equals 0.27 from project SIMAURIF).

This accessibility variable is computed in three ways: in level before the T3 tramway operation (travel times 2005), in level after the T3 tramway operation (travel times 2008), with the same job structure, in variation induced by the T3 tramway computed as the difference between the two levels before and after. However some approximations were needed to get the 2005 travel times as there were not readily available, which may weaken the results attached to the accessibility gain variable.

Different processing of missing values were needed, including imputation by modelling, imputation by hierarchical hot-deck, or inclusion of an "unknown class" for class variables. 


\subsection{Study period and anticipation effects}

If the real estate market were perfectly working, prices would immediately adjust after one property characteristic modification. So, if it were true, and if the public transport accessibility to jobs played a determinant role in property price forming in our study area, the T3 tramway induced accessibility modifications would entail an immediate price adjustment as soon the T3 tramway is put in operation. But the market does not perfectly function and immediate tramway effects may be nearly not existent, because household might have anticipated the tramway implementation and incorporate accessibility gains in sale prices before the tramway operation began.

Reversely, the accessibility gain value might have been incorporated in the prices only after operation began. McDonald \& Osuji (1995), Boarnet \& Chalermpong (2001), Smersh \& Smith (2000), Yiu \& Wong (2005), Deymier (2005), or else Boucq (2008), measure effects before or after the concerned infrastructure building. These authors all show the existence of anticipation effects, and sometime learning effects, but no consensus emerges about the number of years after which tramway effects continue. This may depend on the geographical area, the situation before tramway operation such as good public transport service or not, information provided to households on the project, or other not manageable elements. So we choose a wide enough analysis period to detect these possible anticipation or learning effects, taking into account data availability: 2002 to 2008, 5 years before operation and 2 years after (2008 was the last available year at the start of the study).

\section{RESULTS}

Three different models were performed:

- Model 1 is a hedonic model without taking into account the T3 tramway.

- Model 2 takes into account the T3 tramway by introducing distance between dwelling unit and T3 line as an additional explanatory variable.

- Model 3 takes into account the T3 tramway by introducing accessibility to jobs, in level before the tramway operation, and in variation induced by the tramway.

Several formulations were tested for each of these models, to best grasp the effect of the T3 tramway on housing prices. Only the most relevant formulation will be presented here.

\subsection{Results of model 1 without taking into account tramway T3}

In a first step, a Box-Cox specification for hedonic function $F($.$) was tested. The Box-Cox$ parameter maximizing likelihood is close to zero. So, the logarithm form (log-log) was retained for the dependant variable, following methodology by Ahamada et al. (2007).

The estimated model is:

$\ln (p)=X 1 \beta 1+X 2 \beta 2+\varepsilon$

$13^{\text {th }}$ WCTR, July 15-18, $2013-$ Rio de Janeiro, Brazil 
Where $p$ is housing price vector, $X 1$ intrinsic characteristics observation matrix, and $X 2$ extrinsic characteristics observation matrix. $\varepsilon$ is an independent and identically distributed error term vector. Estimated coefficient vectors $\beta 1$ and $\beta 2$ are given in figure 1 .

The logarithm specified model is estimated by the ordinary least squares method. Table 2 presents global tests statistics.

Table 2: global statistics of model 1c

\begin{tabular}{|l|l|}
\hline Number of observations & 161299 \\
\hline R2 2 adjusted & 0.8781 \\
\hline Degrees of freedom & 0.8779 \\
\hline F & 231 \\
\hline
\end{tabular}

Model $1 \mathrm{c}$ is globally very significant, and the share of explained variance is close to $88 \%$. As in the literature, intrinsic variables, in particular the dwelling unit surface area, play a preponderant role on price determination. Transfer year and month also play an important role. As this variable is in the linear form in a logarithmic model, its effect is multiplicative, which allows taking into account the housing market inflation in price formation. Among extrinsic variables, municipality of neighbourhood plays an important role as well, and this variable captures other price determinants that are linked to the neighbourhood and that are not directly observable.

\begin{tabular}{|c|c|c|c|c|c|c|c|c|c|c|c|c|c|}
\hline \multicolumn{2}{|c|}{ Intrinsic explanatory variables } & Coefficient & $\begin{array}{r}\text { Stand } \\
\text { ard } \\
\text { error }\end{array}$ & t-stat & $\operatorname{Pr}>|t|$ & Variation rate & \multicolumn{2}{|r|}{ Transfer date variables } & Coefficient & $\begin{array}{r}\text { Stand } \\
\text { ard } \\
\text { error }\end{array}$ & t-stat & $\operatorname{Pr}>|t|$ & $\begin{array}{r}\begin{array}{r}\text { Variation } \\
\text { rate }\end{array} \\
\end{array}$ \\
\hline & Constant & 8,477 & 0,031 & 274 & $<, 0001$ & & \multirow{22}{*}{$\begin{array}{r}\text { previous transfer } \\
\text { year }\end{array}$} & avant 1970 & $-0,068$ & 0,005 & -13 & $<, 0001$ & $-7 \%$ \\
\hline & logarithm of surface area & 0,994 & 0,001 & 759 & $<, 0001$ & & & 1971-1980 & $-0,011$ & 0,004 & -3 & 0,0077 & $-1 \%$ \\
\hline logari & thm of surface area per room & $-0,047$ & 0,001 & -39 & $<, 0001$ & & & 1981-1990 & 0,013 & 0,004 & 3 & 0,0006 & $1 \%$ \\
\hline \multirow[b]{6}{*}{ building period } & before 1969 & $-0,042$ & 0,002 & -21 & $<, 0001$ & $-4 \%$ & & 1991 & 0,032 & 0,006 & 6 & $<, 0001$ & $3 \%$ \\
\hline & 1970-1980 & $-0,020$ & 0,003 & -7 & $<, 0001$ & $-2 \%$ & & 1992 & 0,042 & 0,006 & 7 & $<, 0001$ & $4 \%$ \\
\hline & 1981-1991 & 0,016 & 0,004 & 4 & $<, 0001$ & $2 \%$ & & 1993 & 0,048 & 0,005 & 9 & $<, 0001$ & $5 \%$ \\
\hline & $1992-2000$ & 0,091 & 0,004 & 21 & $<, 0001$ & $10 \%$ & & 1994 & 0,049 & 0,005 & 10 & $<, 0001$ & $5 \%$ \\
\hline & $2001-2008$ & 0,241 & 0,003 & 72 & $<, 0001$ & $27 \%$ & & 1995 & 0,045 & 0,005 & 8 & $<, 0001$ & $5 \%$ \\
\hline & unknown (reterence) & 0,000 & & & & & & 1996 & 0,053 & 0,005 & 11 & $<, 0001$ & $5 \%$ \\
\hline \multirow{2}{*}{\multicolumn{2}{|c|}{$\begin{array}{r}\text { basement or ground floor without lift } \\
\text { basement or ground floor with lift }\end{array}$}} & $-0,066$ & 0,006 & -10 & $<, 0001$ & $-6 \%$ & & 1997 & 0,053 & 0,005 & 11 & $<, 0001$ & $5 \%$ \\
\hline & & $-0,046$ & 0,008 & -6 & $<, 0001$ & $-4 \%$ & & 1998 & 0,058 & 0,005 & 13 & $<, 0001$ & $6 \%$ \\
\hline \multicolumn{2}{|c|}{$\begin{array}{l}\text { basement or ground floor with lift } \\
\text { first floor without lift }\end{array}$} & $-0,022$ & 0,006 & -4 & 0,0003 & $-2 \%$ & & 1999 & 0,062 & 0,004 & 14 & $<, 0001$ & $6 \%$ \\
\hline \multirow{15}{*}{$\begin{array}{r}\text { floor number } \\
\text { crossed with lift } \\
\text { presence } \\
\text { unkn }\end{array}$} & first floor with lift & $-0,008$ & 0,006 & -1 & 0,1976 & $-1 \%$ & & 2000 & 0,064 & 0,004 & 15 & $<, 0001$ & $7 \%$ \\
\hline & 2nd floor without lift & 0,012 & 0,006 & 2 & 0,0563 & $1 \%$ & & 2001 & 0,063 & 0,004 & 15 & $<, 0001$ & $6 \%$ \\
\hline & 2nd floor with lift & 0,020 & 0,006 & 3 & 0,0025 & $2 \%$ & & 2002 & 0,041 & 0,004 & 10 & $<, 0001$ & $4 \%$ \\
\hline & 3rd floor without lift & 0,018 & 0,006 & 3 & 0,0034 & $2 \%$ & & 2003 & 0,022 & 0,004 & 5 & $<, 0001$ & $2 \%$ \\
\hline & 3rd floor with lift & 0,033 & 0,006 & 5 & $<, 0001$ & $3 \%$ & & 2004 & 0,026 & 0,004 & 6 & $<, 0001$ & $3 \%$ \\
\hline & 4th floor without lift & 0,021 & 0,006 & 3 & 0,0009 & $2 \%$ & & 2005 & 0,039 & 0,004 & 9 & $<, 0001$ & $4 \%$ \\
\hline & 4th floor with lift & 0,043 & 0,007 & 7 & $<, 0001$ & $4 \%$ & & 2006 & 0,008 & 0,005 & 2 & 0,1173 & $1 \%$ \\
\hline & 5th floor without lift & 0,030 & 0,006 & 5 & $<, 0001$ & $3 \%$ & & 2007 & $-0,005$ & 0,006 & -1 & 0,4296 & $0 \%$ \\
\hline & 5th floor with lift & 0,051 & 0,007 & 8 & $<, 0001$ & $5 \%$ & & 2008 & $-0,029$ & 0,008 & -4 & 0,0002 & $-3 \%$ \\
\hline & 6th floor without litt & 0,014 & 0,007 & 2 & 0,0404 & $1 \%$ & & unknown (reterence) & 0,000 & & & & \\
\hline & bth floor with litt & 0,051 & 0,007 & 7 & $<, 0001$ & $5 \%$ & & & & & & & \\
\hline & 7th, 8th or 9th floor & 0,043 & 0,006 & 7 & $<, 0001$ & $4 \%$ & \multirow{3}{*}{\multicolumn{2}{|c|}{ Extrinsic explanatory variables }} & & Stand & & & \\
\hline & 10th floor or above & $-0,018$ & 0,007 & -2 & 0,0134 & $-2 \%$ & & & & ard & & & Variation \\
\hline & unknown floor without litt & 0,136 & 0,006 & 21 & $<, 0001$ & $15 \%$ & & & Coefficient & error & t-stat & $\operatorname{Pr}>|t|$ & rate \\
\hline & $\begin{array}{l}\text { unknown floor with lift (reference) } \\
\text { und }\end{array}$ & 0,000 & & & & & \multicolumn{2}{|r|}{ Percentage of natural area in block } & 0,012 & 0,006 & 2 & 0,043 & \\
\hline \multirow{20}{*}{ number of garages } & & $-0,180$ & 0,004 & -47 & $<, 0001$ & $-16 \%$ & \multicolumn{2}{|c|}{ Percentage of higher education degrees in IRIS } & 0,210 & 0,014 & 16 & $<, 0001$ & \\
\hline & & $-0,062$ & 0,004 & -17 & $<, 0001$ & $-6 \%$ & \multirow{2}{*}{\multicolumn{2}{|c|}{$\begin{array}{l}\text { Percentage of foreigners in IRIS population } \\
\text { Percentage of households in IRIS where head is }\end{array}$}} & $-0,242$ & 0,021 & -12 & $<, 0001$ & \\
\hline & 2 or more (reterence) & 0,000 & & & & & & & 0,383 & 0,030 & 13 & $<, 0001$ & \\
\hline & & & & & & & Percentage of ho & useholds in IRIS where head is & 0,205 & 0,035 & 6 & $<, 0001$ & \\
\hline & & & & & & & Percentage of hh. i & n IRIS where head is employee & 0,066 & 0,015 & 4 & $<, 0001$ & \\
\hline & & & & & & & Percentage of $h$ & h. in IRIS where head is worker & $-0,208$ & 0,023 & -9 & $<, 0001$ & \\
\hline & & & & & & & Percentage of $p e$ & rsons aged 60 and over in IRIS & 0,111 & 0,016 & 7 & $<, 0001$ & \\
\hline & & & & & & & & MOS single family housing & 0,055 & 0,004 & 14 & $<, 0001$ & $6 \%$ \\
\hline & & & & & & & MOS $n$ & nulti family low rise row housing & 0,020 & 0,003 & 8 & $<, 0001$ & $2 \%$ \\
\hline & & & & & & & MOS multi fa & mily high rise detached housing & $-0,025$ & 0,002 & -11 & $<, 0001$ & $-3 \%$ \\
\hline & & & & & & & & woods and forests & $-0,016$ & 0,002 & -7 & $<, 0001$ & \\
\hline & & & & & & & & gardens and parks & $-0,004$ & 0,001 & -7 & $<, 0001$ & \\
\hline & & & & & & & & sheltered sport facilities & 0,007 & 0,001 & 6 & $<, 0001$ & \\
\hline & & & & & & & & higher education & $-0,009$ & 0,001 & -7 & $<, 0001$ & \\
\hline & & & & & & & & hospitals & $-0,004$ & 0,001 & -6 & $<, 0001$ & \\
\hline & & & & & & & & cemeteries & 0,011 & 0,001 & 10 & $<, 0001$ & \\
\hline & & & & & & & & great cultural facilities & $-0,025$ & 0,001 & -17 & $<, 0001$ & \\
\hline & & & & & & & & habitat gardens & $-0,002$ & 0,001 & -2 & 0,1076 & \\
\hline & & & & & & & logarithm of & all shopping facilities & 0,005 & 0,001 & 5 & $<, 0001$ & \\
\hline & & & & & & & distance to & ZAC urban development zone & 0,008 & 0,001 & 12 & $<, 0001$ & \\
\hline
\end{tabular}

Figure 1: coefficients and statistics of model 1 (model 1c) 


\begin{tabular}{|c|c|c|c|c|c|c|c|c|c|c|c|c|c|}
\hline & Transfer date variables & Coefficient & $\begin{array}{r}\text { Stand } \\
\text { ard } \\
\text { error }\end{array}$ & t-stat & $\operatorname{Pr}>|t|$ & Variation rate & & Extrinsic explanatory variables & Coefficient & $\begin{array}{r}\text { Stand } \\
\text { ard } \\
\text { error }\end{array}$ & t-stat & $\operatorname{Pr}>|t|$ & $\begin{array}{r}\text { Variation } \\
\text { rate }\end{array}$ \\
\hline & January 2002 & $-0,644$ & 0,009 & -68 & $<, 0001$ & $-47 \%$ & & $\begin{array}{rr}\text { Alfortville } \\
\end{array}$ & 0,131 & 0,008 & 17 & $<, 0001$ & $14 \%$ \\
\hline & February 2002 & $-0,633$ & 0,010 & -65 & $<, 0001$ & $-47 \%$ & & Arcueil & 0,154 & 0,010 & 15 & $<, 0001$ & $17 \%$ \\
\hline & March 2002 & $-0,639$ & 0,010 & -67 & $<, 0001$ & $-47 \%$ & & Bagneux & 0,145 & 0,009 & 15 & $<, 0001$ & $16 \%$ \\
\hline & April 2002 & $-0,632$ & 0,009 & -67 & $<, 0001$ & $-47 \%$ & & Boulogne-Billancourt & 0,528 & 0,007 & 76 & $<, 0001$ & $70 \%$ \\
\hline & May 2002 & $-0,592$ & 0,009 & -63 & $<, 0001$ & $-45 \%$ & & Bourg-la-Reine & 0,214 & 0,023 & 9 & $<, 0001$ & $24 \%$ \\
\hline & June 2002 & $-0,597$ & 0,009 & -65 & $<, 0001$ & $-45 \%$ & & Cachan & 0,092 & 0,009 & 11 & $<, 0001$ & $10 \%$ \\
\hline & July 2002 & $-0,579$ & 0,009 & -65 & $<, 0001$ & $-44 \%$ & & Charenton-le-Pont & 0,389 & 0,009 & 42 & $<, 0001$ & $48 \%$ \\
\hline & August 2002 & $-0,562$ & 0,010 & -55 & $<, 0001$ & $-43 \%$ & & Châtillon & 0,253 & 0,007 & 34 & $<, 0001$ & $29 \%$ \\
\hline & September 2002 & $-0,563$ & 0,009 & -62 & $<, 0001$ & $-43 \%$ & & Clamart & 0,272 & 0,008 & 33 & $<, 0001$ & $31 \%$ \\
\hline & October 2002 & $-0,566$ & 0,009 & -60 & $<, 0001$ & $-43 \%$ & & Fontenay-aux-Roses & 0,227 & 0,020 & 11 & $<, 0001$ & $26 \%$ \\
\hline & November 2002 & $-0,555$ & 0,010 & -54 & $<, 0001$ & $-43 \%$ & & Gentilly & 0,226 & 0,011 & 21 & $<, 0001$ & $25 \%$ \\
\hline & December 2002 & $-0,543$ & 0,009 & -58 & $<, 0001$ & $-42 \%$ & & Haÿ-les-Roses (L') & 0,065 & 0,047 & 1 & 0,1661 & $7 \%$ \\
\hline & January 2003 & $-0,523$ & 0,010 & -55 & $<, 0001$ & $-41 \%$ & & Issy-les-Moulineaux & 0,421 & 0,007 & 58 & $<, 0001$ & $52 \%$ \\
\hline & February 2003 & $-0,528$ & 0,010 & -55 & $<, 0001$ & $-41 \%$ & & Ivry-sur-Seine & 0,136 & 0,007 & 20 & $<, 0001$ & $15 \%$ \\
\hline & March 2003 & $-0,514$ & 0,010 & -54 & $<, 0001$ & $-40 \%$ & & Kremlin-Bicêtre (Le) & 0,210 & 0,009 & 23 & $<, 0001$ & $23 \%$ \\
\hline & April 2003 & $-0,512$ & 0,009 & -55 & $<, 0001$ & $-40 \%$ & & Maisons-Alfort & 0,183 & 0,015 & 12 & $<, 0001$ & $20 \%$ \\
\hline & May 2003 & $-0,497$ & 0,010 & -51 & $<, 0001$ & $-39 \%$ & & Malakoff & 0,387 & 0,008 & 46 & $<, 0001$ & $47 \%$ \\
\hline & June 2003 & $-0,473$ & 0,009 & -52 & $<, 0001$ & $-38 \%$ & & Meudon & 0,316 & 0,009 & 36 & $<, 0001$ & $37 \%$ \\
\hline & July 2003 & $-0,464$ & 0,009 & -53 & $<, 0001$ & $-37 \%$ & & Montrouge & 0,405 & 0,007 & 58 & $<, 0001$ & $50 \%$ \\
\hline & August 2003 & $-0,441$ & 0,010 & -42 & $<, 0001$ & $-36 \%$ & & Paris01Q1 & 1,390 & 0,055 & 25 & $<, 0001$ & $302 \%$ \\
\hline & September 2003 & $-0,438$ & 0,009 & -49 & $<, 0001$ & $-35 \%$ & & Paris03Q2 & 0,927 & 0,089 & 10 & $<, 0001$ & $153 \%$ \\
\hline & October 2003 & $-0,439$ & 0,009 & -47 & $<, 0001$ & $-36 \%$ & & Paris03Q3 & 0,911 & 0,023 & 40 & $<, 0001$ & $149 \%$ \\
\hline & November 2003 & $-0,433$ & 0,010 & -43 & $<, 0001$ & $-35 \%$ & & Paris04Q1 & 1,363 & 0,153 & 9 & $<, 0001$ & $291 \%$ \\
\hline & December 2003 & $-0,407$ & 0,009 & -44 & $<, 0001$ & $-33 \%$ & & Paris04Q2 & 0,844 & 0,014 & 62 & $<, 0001$ & $133 \%$ \\
\hline & January 2004 & $-0,384$ & 0,009 & -41 & $<, 0001$ & $-32 \%$ & & Paris04Q3 & 0,859 & 0,012 & 73 & $<, 0001$ & $136 \%$ \\
\hline & February 2004 & $-0,401$ & 0,010 & -42 & $<, 0001$ & $-33 \%$ & & Paris04Q4 & 1,166 & 0,016 & 75 & $<, 0001$ & $221 \%$ \\
\hline & March 2004 & $-0,391$ & 0,009 & -42 & $<, 0001$ & $-32 \%$ & & Paris05Q1 & 0,875 & 0,011 & 77 & $<, 0001$ & $140 \%$ \\
\hline & April 2004 & $-0,370$ & 0,009 & -39 & $<, 0001$ & $-31 \%$ & & Paris05Q2 & 0,794 & 0,011 & 71 & $<, 0001$ & $121 \%$ \\
\hline & May 2004 & $-0,359$ & 0,009 & -38 & $<, 0001$ & $-30 \%$ & & Paris05Q3 & 0,891 & 0,011 & 83 & $<, 0001$ & $144 \%$ \\
\hline & June 2004 & $-0,343$ & 0,009 & -39 & $<, 0001$ & $-29 \%$ & & Paris05Q4 & 0,939 & 0,013 & 73 & $<, 0001$ & $156 \%$ \\
\hline & July 2004 & $-0,328$ & 0,009 & -38 & $<, 0001$ & $-28 \%$ & & Paris06Q1 & 1,055 & 0,012 & 86 & $<, 0001$ & $187 \%$ \\
\hline & August 2004 & $-0,306$ & 0,010 & -30 & $<, 0001$ & $-26 \%$ & & Paris06Q2 & 1,047 & 0,012 & 85 & $<, 0001$ & $185 \%$ \\
\hline & September 2004 & $-0,309$ & 0,009 & -35 & $<, 0001$ & $-27 \%$ & & Paris06Q3 & 0,968 & 0,010 & 94 & $<, 0001$ & $163 \%$ \\
\hline & October 2004 & $-0,301$ & 0,009 & -33 & $<, 0001$ & $-26 \%$ & & Paris06Q4 & 1,128 & 0,015 & 74 & $<, 0001$ & $209 \%$ \\
\hline & November 2004 & $-0,276$ & 0,010 & -28 & $<, 0001$ & $-24 \%$ & & Paris07Q1 & 1,094 & 0,012 & 93 & $<, 0001$ & $199 \%$ \\
\hline & December 2004 & $-0,288$ & 0,009 & -32 & $<, 0001$ & $-25 \%$ & & Paris07Q2 & 1,067 & 0,013 & 80 & $<, 0001$ & $191 \%$ \\
\hline & January 2005 & $-0,274$ & 0,009 & -30 & $<, 0001$ & $-24 \%$ & & Paris07Q3 & 0,924 & 0,011 & 83 & $<, 0001$ & $152 \%$ \\
\hline & February 2005 & $-0,267$ & 0,009 & -29 & $<, 0001$ & $-23 \%$ & & Paris07Q4 & 0,916 & 0,010 & 91 & $<, 0001$ & $150 \%$ \\
\hline & March 2005 & $-0,260$ & 0,009 & -28 & $<, 0001$ & $-23 \%$ & & Paris08Q1 & 1,096 & 0,017 & 63 & $<, 0001$ & $199 \%$ \\
\hline & April 2005 & $-0,245$ & 0,009 & -26 & $<, 0001$ & $-22 \%$ & & Paris08Q4 & 0,832 & 0,133 & 6 & $<, 0001$ & $130 \%$ \\
\hline & May 2005 & $-0,235$ & 0,009 & -26 & $<, 0001$ & $-21 \%$ & & Paris11Q2 & 0,665 & 0,019 & 35 & $<, 0001$ & $94 \%$ \\
\hline & June 2005 & $-0,217$ & 0,009 & -25 & $<, 0001$ & $-20 \%$ & & Paris11Q3 & 0,668 & 0,009 & 75 & $<, 0001$ & $95 \%$ \\
\hline & July 2005 & $-0,198$ & 0,009 & -23 & $<, 0001$ & $-18 \%$ & & Paris11Q4 & 0,645 & 0,008 & 84 & $<, 0001$ & $91 \%$ \\
\hline & August 2005 & $-0,177$ & 0,010 & -18 & $<, 0001$ & $-16 \%$ & & Paris12Q1 & 0,570 & 0,009 & 60 & $<, 0001$ & $77 \%$ \\
\hline & September 2005 & $-0,166$ & 0,009 & -19 & $<, 0001$ & $-15 \%$ & & Paris12Q2 & 0,623 & 0,008 & 79 & $<, 0001$ & $86 \%$ \\
\hline & October 2005 & $-0,163$ & 0,009 & -17 & $<, 0001$ & $-15 \%$ & & Paris12Q3 & 0,586 & 0,011 & 52 & $<, 0001$ & $80 \%$ \\
\hline & November 2005 & $-0,160$ & 0,009 & -17 & $<, 0001$ & $-15 \%$ & & Paris12Q4 & 0,653 & 0,009 & 77 & $<, 0001$ & $92 \%$ \\
\hline & December 2005 & $-0,159$ & 0,009 & -18 & $<, 0001$ & $-15 \%$ & & Paris13Q1 & 0,610 & 0,011 & 58 & $<, 0001$ & $84 \%$ \\
\hline & January 2006 & $-0,143$ & 0,009 & -15 & $<, 0001$ & $-13 \%$ & & Paris13Q2 & 0,490 & 0,009 & 55 & $<, 0001$ & $63 \%$ \\
\hline & February 2006 & $-0,137$ & 0,009 & -14 & $<, 0001$ & $-13 \%$ & & Paris13Q3 & 0,585 & 0,008 & 78 & $<, 0001$ & $80 \%$ \\
\hline & March 2006 & $-0,139$ & 0,009 & -15 & $<, 0001$ & $-13 \%$ & & Paris13Q4 & 0,702 & 0,010 & 71 & $<, 0001$ & $102 \%$ \\
\hline & April 2006 & $-0,139$ & 0,009 & -15 & $<, 0001$ & $-13 \%$ & & Paris14Q1 & 0,857 & 0,010 & 83 & $<, 0001$ & $136 \%$ \\
\hline & May 2006 & $-0,119$ & 0,009 & -13 & $<, 0001$ & $-11 \%$ & & Paris14Q2 & 0,719 & 0,010 & 74 & $<, 0001$ & $105 \%$ \\
\hline & June 2006 & $-0,114$ & 0,009 & -13 & $<, 0001$ & $-11 \%$ & & Paris14Q3 & 0,707 & 0,008 & 87 & $<, 0001$ & $103 \%$ \\
\hline & July 2006 & $-0,088$ & 0,009 & -10 & $<, 0001$ & $-8 \%$ & & Paris14Q4 & 0,690 & 0,008 & 84 & $<, 0001$ & $99 \%$ \\
\hline & August 2006 & $-0,064$ & 0,010 & -6 & $<, 0001$ & $-6 \%$ & & Paris15Q1 & 0,698 & 0,008 & 87 & $<, 0001$ & $101 \%$ \\
\hline & September 2006 & $-0,086$ & 0,009 & -9 & $<, 0001$ & $-8 \%$ & & Paris15Q2 & 0,737 & 0,009 & 81 & $<, 0001$ & $109 \%$ \\
\hline & October 2006 & $-0,076$ & 0,009 & -8 & $<, 0001$ & $-7 \%$ & & Paris15Q3 & 0,767 & 0,009 & 88 & $<, 0001$ & $115 \%$ \\
\hline & November 2006 & $-0,065$ & 0,010 & -6 & $<, 0001$ & $-6 \%$ & & Paris15Q4 & 0,742 & 0,008 & 90 & $<, 0001$ & $110 \%$ \\
\hline & December 2006 & $-0,078$ & 0,009 & -9 & $<, 0001$ & $-7 \%$ & & Paris16Q1 & 0,730 & 0,008 & 88 & $<, 0001$ & $108 \%$ \\
\hline & January 2007 & $-0,067$ & 0,009 & -7 & $<, 0001$ & $-7 \%$ & & Paris16Q2 & 0,817 & 0,009 & 88 & $<, 0001$ & $126 \%$ \\
\hline & February 2007 & $-0,058$ & 0,010 & -6 & $<, 0001$ & $-6 \%$ & & Paris16Q3 & 0,817 & 0,010 & 80 & $<, 0001$ & $126 \%$ \\
\hline & March 2007 & $-0,049$ & 0,009 & -5 & $<, 0001$ & $-5 \%$ & & Paris16Q4 & 0,856 & 0,010 & 83 & $<, 0001$ & $135 \%$ \\
\hline & April 2007 & $-0,048$ & 0,010 & -5 & $<, 0001$ & $-5 \%$ & & Paris20Q4 & 0,590 & 0,017 & 35 & $<, 0001$ & $80 \%$ \\
\hline & May 2007 & $-0,039$ & 0,009 & -4 & $<, 0001$ & $-4 \%$ & & Saint-Cloud & 0,346 & 0,011 & 31 & $<, 0001$ & $41 \%$ \\
\hline & June 2007 & $-0,029$ & 0,009 & -3 & 0,0013 & $-3 \%$ & & Saint-Mandé & 0,473 & 0,014 & 34 & $<, 0001$ & $60 \%$ \\
\hline & July 2007 & $-0,031$ & 0,009 & -4 & 0,0004 & $-3 \%$ & & Saint-Maurice & 0,368 & 0,014 & 27 & $<, 0001$ & $44 \%$ \\
\hline & August 2007 & $-0,035$ & 0,010 & -3 & 0,0005 & $-3 \%$ & & Sèvres & 0,216 & 0,019 & 11 & $<, 0001$ & $24 \%$ \\
\hline & September 2007 & $-0,017$ & 0,009 & -2 & 0,0577 & $-2 \%$ & Paris & Vanves & 0,362 & 0,008 & 43 & $<, 0001$ & $44 \%$ \\
\hline & October 2007 & $-0,011$ & 0,009 & -1 & 0,2446 & $-1 \%$ & neighbourhood or & Villejuif & 0,116 & 0,007 & 17 & $<, 0001$ & $12 \%$ \\
\hline & November 2007 & $-0,006$ & 0,010 & -1 & 0,5682 & $-1 \%$ & municipality & Vitry-sur-Seine (reterence) & 0,000 & & & & \\
\hline & December 2007 & $-0,002$ & 0,009 & 0 & 0,8072 & $0 \%$ & & avenue & 0,015 & 0,005 & 3 & 0,0048 & $2 \%$ \\
\hline & January 2008 & 0,012 & 0,009 & 1 & 0,2038 & $1 \%$ & & boulevard & 0,001 & 0,006 & 0 & 0,7961 & $0 \%$ \\
\hline & February 2008 & 0,006 & 0,010 & 1 & 0,5092 & $1 \%$ & & passage, place, quai & 0,019 & 0,006 & 3 & 0,004 & $2 \%$ \\
\hline & March 2008 & 0,010 & 0,010 & 1 & 0,2957 & $1 \%$ & & rue & 0,008 & 0,005 & 1 & 0,1476 & $1 \%$ \\
\hline & April 2008 & 0,017 & 0,010 & 2 & 0,0665 & $2 \%$ & & square,villa,voie,route & 0,026 & 0,007 & 4 & 0,0003 & $3 \%$ \\
\hline & May 2008 & 0,023 & 0,010 & 2 & 0,0202 & $2 \%$ & Street type & other (reterence) & 0,000 & & & & \\
\hline & June 2008 & 0,031 & 0,009 & 3 & 0,001 & $3 \%$ & logarithme & e of distance to St Lazare station & & & & & \\
\hline & July 2008 & 0,037 & 0,009 & 4 & $<, 0001$ & $4 \%$ & addre & ess on boulevard des Maréchaux & $-0,085$ & 0,010 & -9 & $<, 0001$ & $-8 \%$ \\
\hline & August 2008 & 0,037 & 0,011 & 3 & 0,0008 & $4 \%$ & distance to & 1) $0-200 \mathrm{~m}$ before & 0,028 & 0,017 & 2 & 0,0975 & $3 \%$ \\
\hline & September 2008 & 0,037 & 0,009 & 4 & $<, 0001$ & $4 \%$ & Olympiades station & 2) $0-200 \mathrm{~m}$ after & 0,024 & 0,032 & 1 & 0,4492 & $2 \%$ \\
\hline & October 2008 & 0,029 & 0,010 & 3 & 0,0026 & $3 \%$ & and transfer & 3) $200-400 \mathrm{~m}$ before & 0,043 & 0,013 & 3 & 0,0009 & $4 \%$ \\
\hline transfer year and & November 2008 & 0,007 & 0,011 & 1 & 0,5432 & $1 \%$ & before/after & 4) $200-400 \mathrm{~m}$ after & 0,084 & 0,022 & 4 & 0,0002 & $9 \%$ \\
\hline & December 2008 (reterence) & 0,000 & & & & & Olympiades & 5) $>400 \mathrm{~m}$ (reterence) & 0,000 & & & & \\
\hline
\end{tabular}

Figure 1: coefficients and statistics of model 1 (model 1c) (continued) 
The effects of explanatory variables on housing prices are not surprising, and support the empirical literature (e.g. Cavailhès (2005), Gravel et al. (2002), Özdilek et al. (2002), Cornuel et al. (2003), Bowes \& Ihlanfeldt (2001), Boucq (2008)).

Let's interpret the results by variable category.

\section{Intrinsic variables}

Housing price increases with the dwelling unit surface area, in a quasi-proportional way (estimated elasticity $0.994 \pm 0.001$, the significant small gap with one gives a premium to small flats). The number of rooms was not included in the model, as it is strongly correlated with surface area (linear correlation coefficient 0.86 ), and the most significant variable of the two was retained. However, another variable, built from the previous two, was added: average surface by room, not too much correlated with surface area (linear correlation coefficient 0.23). Marchand \& Skhiri (1995) also had a similar specification by retaining the number of rooms and the surface area per room. In the retained model, this variable plays a significant and negative role on the dwelling price determination. Thus, everything else being equal, in particular surface area, housing price decreases with average surface area per room, which means that it increases with the number of rooms, for a given surface area. Both effects may reflect the shortage of dwellings in Paris, which makes households search for smaller flats with the needed number of bedrooms.

Housing price decreases with remoter building period. As compared with dwellings with missing building period, the variation rate induced by a building before 1980 is negative but small (-4\% before $1969,-2 \%$ for $1970-1980)$; it is positive and small for period $1981-1991$ $(+1.5 \%)$, and then increases rather strongly for period $1992-2000(+9.5 \%)$ and very strongly for period after $2001(+27 \%)$. This reflects the better standards of the most recent buildings.

These results are consistent with those by Cavailhès (2005), who estimates a hedonic model for rents in 1996, whole of France, Paris, and each urban area size. In Paris, the highest rents are obtained for the building period after 1989, followed by 1982-1989. In their model, Marchand \& Skhiri (1995) introduce building age, in a continuous form, by means of a quadratic function. They get a negative parameter for building age and a positive one for squared building age: the negative effect of building age is decreasing, which is consistent with our results.

The effect of a lift on flat prices varies according to the floor level. So the floor variable was crossed with the dummy lift for flats up to 6th floor. Beyond, the number of dwellings without lift is too small to get robust results. Lift is systematically valued (figure 2 ) and prices increase with floor level up to the fifth floor without lift, and up to the sixth floor with a lift. Then price decreases with floor level, particularly for flats located on the 10th floor or above. Higher flats get more daylight, but high-rise buildings are less appreciated in Paris. 
Should any new light rail line provide real estate gains, or not? The case of Paris T3 line PAPON, Francis; NGUYEN-LUONG, Dany; BOUCQ, Elise

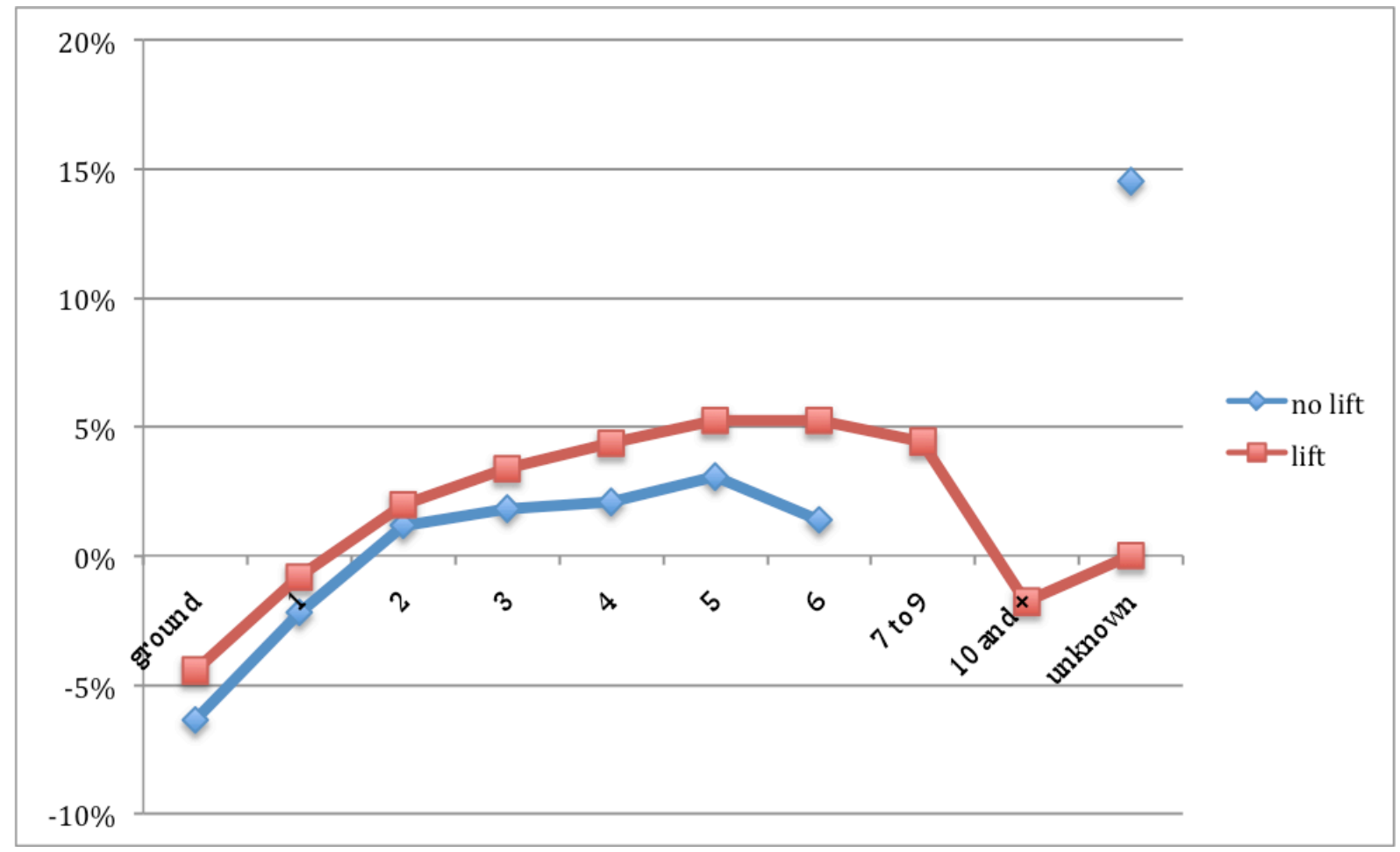

Figure 2: percentage change according to floor level and lift (model 1c, reference: with lift, floor unknown)

A last, the dwelling price increases with the number of garages: compared to dwellings with two garages or more, the variation rate induced by the lack of garage is $-16.5 \%$, and $-6 \%$ for dwellings with only one garage.

\section{Variables relative to transfer dates}

Figure 3 represents the variation rate induced by transfer month and year, compared with December 2008. Price is all the higher as transaction is more recent, but for the last three months of 2008 when a slight decrease is observed. The variation rate increases rather steadily between January 2002 and July 2008, from $-47 \%$ to $+3,8 \%$. Then follow three plateau months, then a decrease. 


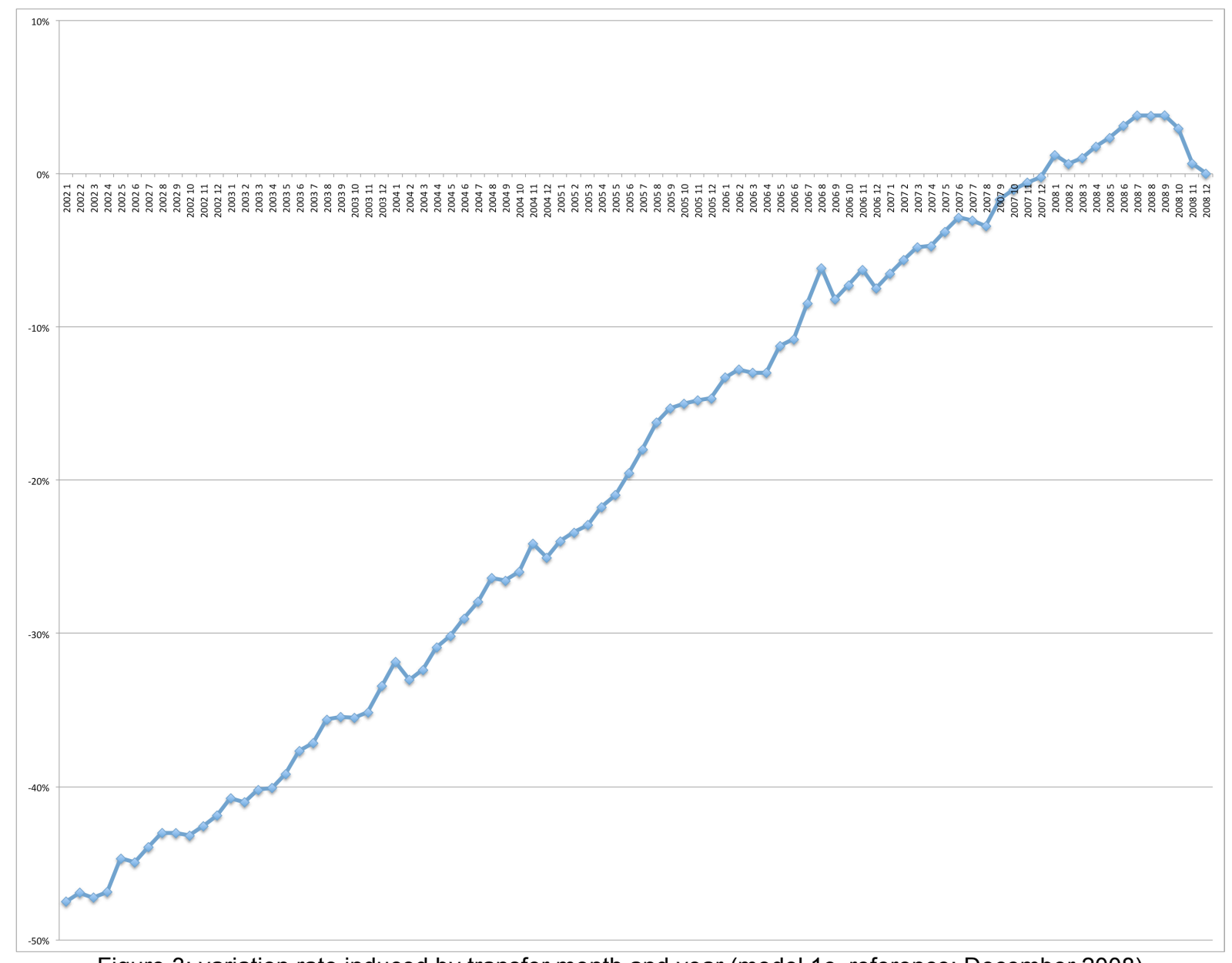

Figure 3: variation rate induced by transfer month and year (model 1c, reference: December 2008)

The dwelling price also varies according to the previous transfer year, but with a weaker range than that induced by the current transfer year. Until 2001, the more recent the previous transfer is, the highest the price is. The trend is reversed from 2002: price is all the lowest as previous transfer is recent, but for a small peak in 2005.

\section{Extrinsic variables}

Neighbourhood (in Paris) or municipality plays an important role in real estate price determination. Variation rates induced by the sold unit geographical location strongly vary from one neighbourhood or one municipality to another: rates range from $0 \%$ for reference Vitry-sur-Seine to $300 \%$. Paris is systematically more valued than other municipalities, and in Paris some neighbourhoods are more valued than others, in particular neighbourhood SaintGermain-l'Auxerrois (1st neighbourhood in 1st arrondissement), neighbourhood Saint-Merri (1st neighbourhood in 4th arrondissement), neighbourhood Notre-Dame (4th neighbourhood in 4th arrondissement), and neighbourhood Saint-Germain-des-Prés (4th neighbourhood in 6 th arrondissement), with a variation rate above $200 \%$.

As in Glachant et al. (2008), street type also impacts prices, but for more robustness some items with small sample size and similar price effects were grouped together. Among street types with large sample size, avenues, which represent $16 \%$ of transactions, are the most 
valued. Boulevards, with $7 \%$ of transactions, are the less valued, in particular boulevard des Maréchaux ( $8 \%$ of addresses are located on a boulevard).

As far as land use variables are concerned: real estate prices are higher for properties located in a single-family housing or multi-family low-rise row-housing polygon, and lower for those located in a multi-family high-rise detached housing one. Moreover, housing price increases with proximity to some green space: woods and forests, gardens and parks, and habitat gardens. Price also increases with proximity to some local public facilities such as hospitals, higher education institutions and great cultural facilities, which confirms the local public goods capitalization hypothesis by Tiebout (1956). Reversely, price increases with the remoteness to cemeteries, sheltered sport facilities, ZAC urban development zone and all shopping facilities. This last point can look surprising, but it was already present in Boucq (2008) and could be explained by the fact that shopping facilities are often located in undesirable or unfavoured areas.

Proximity in a 200 meters radius to Olympiades metro station has no effect on dwelling prices before or after the station opening in end of June 2007. On the contrary, in a 200-400 meters ring around the station, housing price was significantly higher before station opening (by some 4,5\%), and this price difference doubled after the station opening. But the before/after difference is not significant at the $95 \%$ threshold.

As far as the IRIS population zone characteristics are concerned, those with a high proportion of high social category (retailers, craftsmen, or business manager), higher education degrees, unemployed, persons aged over 60, are more valued. Reversely, zones with a high share of foreigners, or workers, are less valued.

Finally, housing price is higher in blocks with natural space.

\subsection{Results of model 2 taking into account tramway T3 with distance}

When distance to the T3 tramway is introduced in the previous model, the distance to the line is more significant than that to the nearest T3 station and is retained. As the effect of the distance on prices is not continuous, distance is introduced as a class variable. The intervals must be short enough for accuracy, but not too much out of sample size concerns. Distance is oriented by making the distinction of which side of the line the dwelling unit is located. As this oriented distance to the T3 line is highly correlated to the distance to the centre of Paris, which strongly impact prices within each neighbourhood, the distance to the centre of Paris is also introduced in the model (the best centre used is the one with the most significant effect among several tested: gare St Lazare). The oriented distance to the T3 line is then crossed with the transaction date dummy before/after T3 operation.

Model 2 results show identical coefficients (within confidence intervals bounds) as model 1 for intrinsic variables, transfer year variables, and some extrinsic variables. Most model neighbourhood variable coefficients, coefficients for street type and distance to Olympiades and some of other extrinsic variables are slightly but significantly reduced in model 2 with

$13^{\text {th }}$ WCTR, July 15-18, $2013-$ Rio de Janeiro, Brazil 
accessibility because of the introduction of the distance to Paris centre variable that captures a part of the location effect. However, the sign of the coefficients do not change.

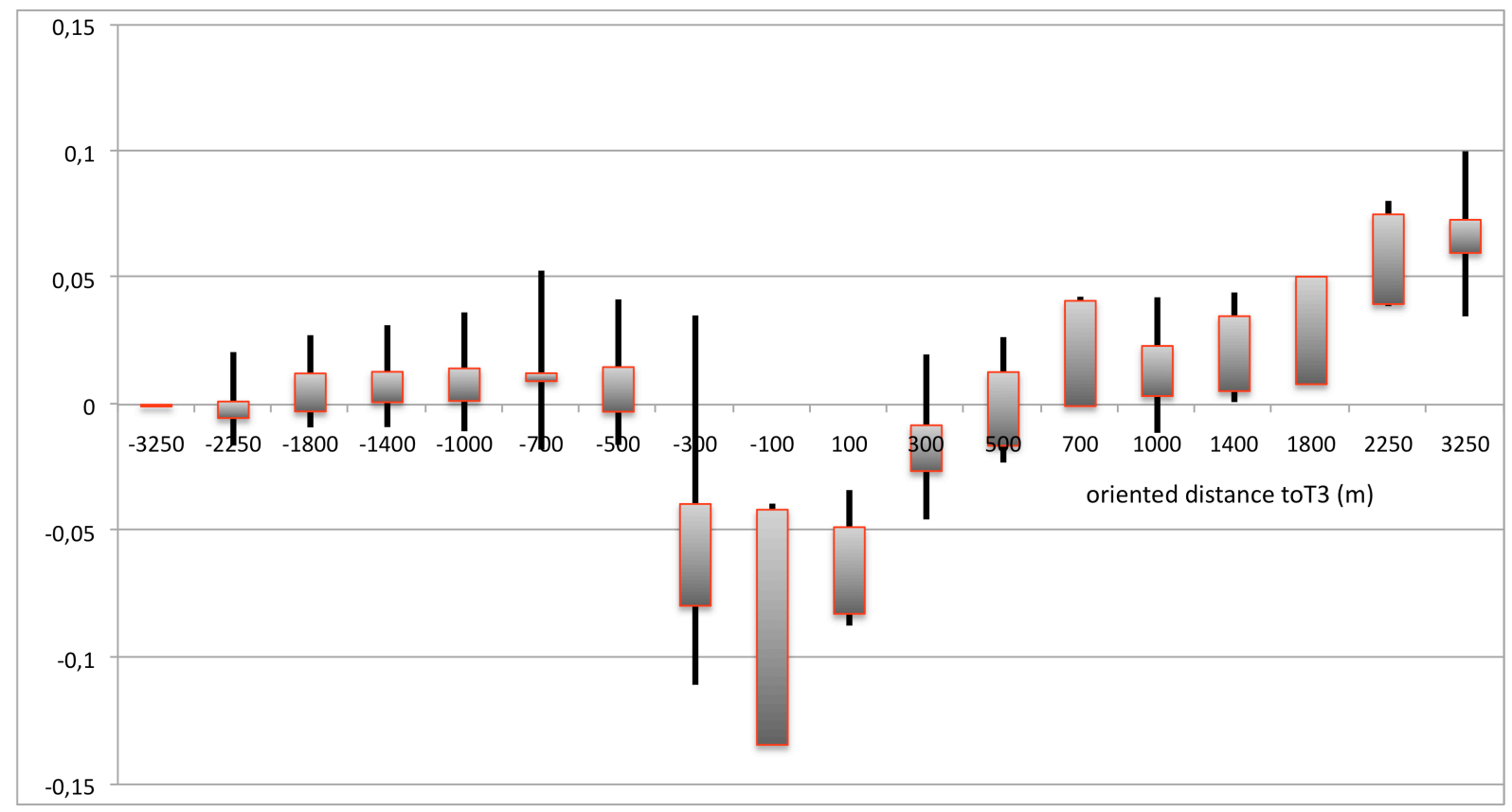

Figure 4: confidence bars at $95 \%$ level of parameters of oriented distance classes to the T3 line, before and after operation (model 2.3c, reference: over 2500 metres South)

Figure 4 reads as follows: the confidence bar before operation is the black bar emerging at the bottom of the rectangle; the confidence bar after operation is the black bar emerging at the top of the rectangle; if the rectangle

is white, the after bar is significantly above the before bar; if the rectangle is black, both bars overlap in the rectangle.

The parameters of oriented distance classes are slightly higher after operation as compared to before operation for nearly all distance classes, but that below 200 meters South of the line. Apart for this class, the gap is higher in the South. However, if the model error margin is taken into account, no gap is significant at the $95 \%$ threshold (figure 4 ).

\subsection{Results of model 3 taking into account tramway $T 3$ accessibility gains}

Accessibility to jobs (in logarithm) is introduced in the model, as well as accessibility gains induced by T3 operation (also in logarithm), crossed with transaction year to take into account anticipation or learning effects. Moreover, distance to T3 is introduced in four classes (less than 200 metres and 200 to 400 metres crossed with North and South), which are also crossed with the dummy transaction before/after T3 operation.

Except for new variables, coefficients for model 3 variables are identical (within confidence intervals bounds) to those of model 2. Models 2 and 3 give similar coefficients for oriented distance to T3 crossed with before/after.

Accessibility gains get a significant negative but small effect only in 2002 and 2005 (figure 5). 


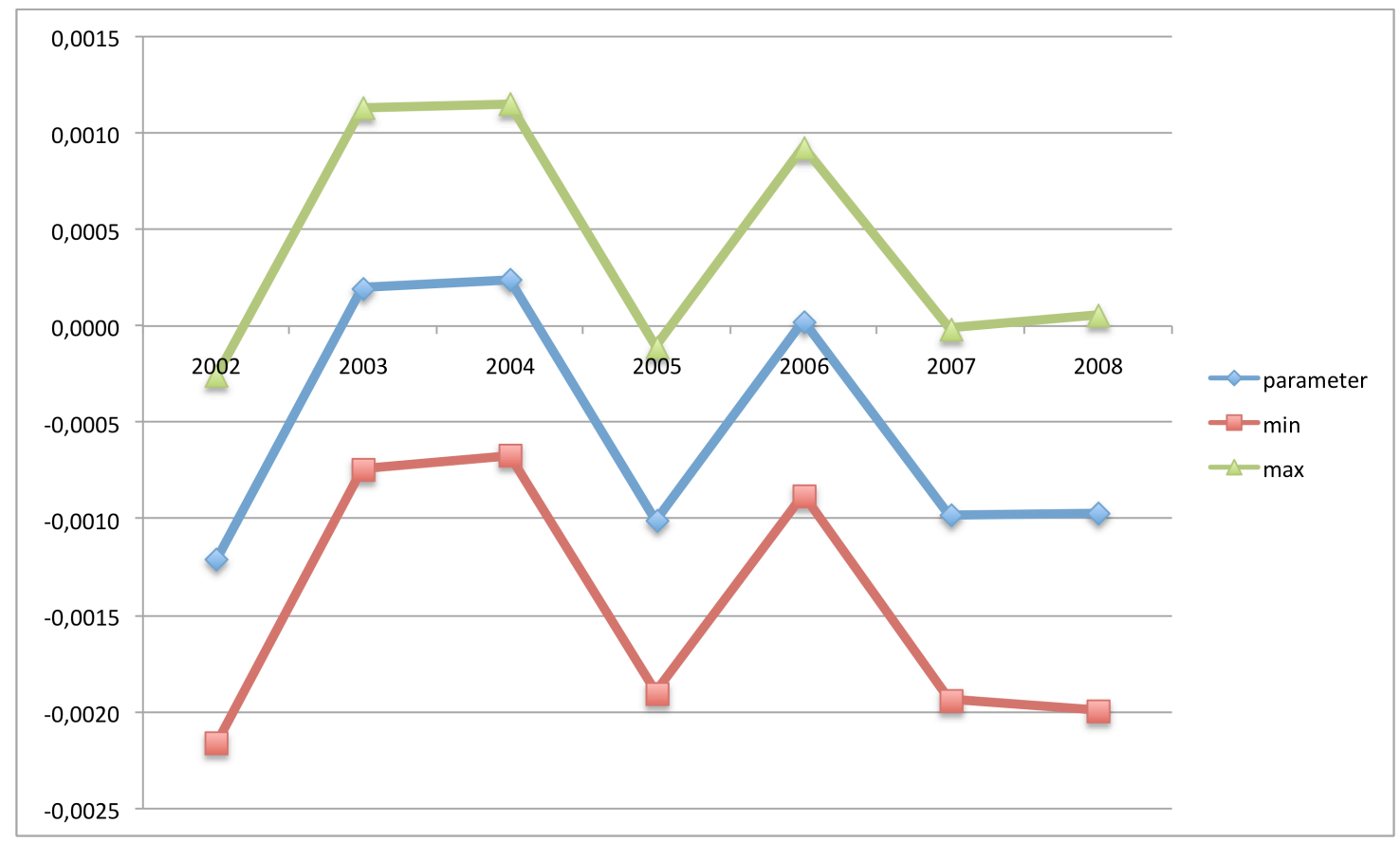

Figure 5: elasticity of dwelling prices to T3 accessibility gains, according to transaction year, and confidence interval at the $95 \%$ level.

\subsection{Estimation of real estate gains}

A price increase by $5 \%$ was observed in the 200 to 400 metres strip south of the T3 line after its operation began, and by a lower rate beyond, but this increase is not significantly different from zero. On the contrary, a weak significant negative effect of the T3 accessibility gain was detected in 2002, 2005 and 2007, but it is difficult to attribute it to the T3 with certainty.

Thus, it is not possible to compute real estate gains or losses brought by the T3 that would be statistically significant and reliable as regards their causality. However, the most comprehensive and accurately located data were used for all transactions passed in a 4000 meters radius from the T3 from 2002 to 2008; no better data could have been used. It can be concluded that it is not possible to detect any effect of the operation of the T3 tramway on the dwelling values.

\section{CONCLUSIONS/IMPLICATIONS}

At the end of this study, three main conclusions can be cleared.

First, from a methodological point of view, the study implemented state of the art data and statistical methods. Methodological data weaknesses, often pointed out in the literature, were corrected and cannot be used to explain inaccurate or uncertain outcomes, but for one variable (the public transport accessibility gain to jobs) that was computed with a complex but approximate manner due to a missing piece of data. Hedonic modelling is a powerful 
statistical method, but must be handled with rigour by skilled econometrists. It consisted in testing some fifteen explanatory models in a log-log functional form by incrementally introducing regressors and avoiding statistical biases from spatial autocorrelation and multicolinearity. Some fifty variables, not counting crossed variables, were taken into account. They can be classified into four categories: intrinsic variables, extrinsic non-transport variables, transfer date variables, and accessibility variables.

Hedonic modelling is essential to quantify the specific effects of a new infrastructure on real estate prices, and its use gets a consensus in the scientific community. However, it is important to beforehand carry out a descriptive space-time and cartographic descriptive analysis of geo-located data, which is not always done in such studies, and to pass in parallel a qualitative survey to real estate agents who detain a thorough knowledge of the local context and of the demand evolution before/after infrastructure operation. Thus, descriptive analysis, econometric analysis and qualitative analysis are additional approaches.

Then, from the point of view of the study statistical results, the retained econometric models are very significant, with some $88 \%$ of variance explained. They evidence the main determinants: dwelling surface area, economic trend and neighbourhood. They also set the role of many other intrinsic and extrinsic characteristics of the sold unit. The share of intrinsic variables amounts to about three quarters of the price. These results are robust and parameters vary little if the model specifications are changed.

As far as transport variables are concerned, including distance to the T3 tramway route, models clearly show depreciation next to the route (some $5 \%$ less than 200 metres North et 400 metres South). But the existence of this depreciation does not mean that the cause is the T3, given the historical image of the area. Besides, the observed ceteris paribus price evolutions after the T3 operation in different stripes along the route are not significant, though they are positive from 200 meters South of the line (+5\% 200 to 400 metres, $+3 \% 600$ to 800 metres), in spite of the real estate crisis that struck more suburban areas than Paris.

As regards the T3 induced accessibility gain, it looks correlated with a weak and significant loss in 2002, 2005 and 2007, or after operation compared with before operation, in the order of magnitude of one thousandth of the value of the concerned dwellings. But it is unlikely that those losses be due to the anticipation of accessibility variation brought by the tramway, or to a relative disappointment about its quality of service after its operation. Other effects may have been captured by this variable, such as the hindrance from the works before the tramway operation, or the decrease in road traffic fluidity during the works and after operation. Anyway, the tramway time gain compared with the previous PC1 bus service is low (less than 4 minutes from one end to another), and it is consistent with other studies selected from the literature not to observe in this case any sensitive effect on prices. Finally, the outcome is that no significant effect of the T3 tramway operation on real estate prices was proven. 
Nevertheless, it could have been expected that the environment and landscape improvement would have brought a gain in the vicinity of the line. But this was not observed in 2007 and 2008, two years only after the T3 began operation. Maybe it is due to a difficult real estate situation, and the following years may show an increase in the area attractiveness. But a new evaluation will be needed to know it.

These results are consistent to the recent cost-benefit analysis of the T3 tramway (Prud'homme et al., 2011) finding that the new line produced a net loss for travellers, as increase in road congestion offsets timesavings to public transport users. In fact, tramway users' timesavings were lower than expected, and difficult to compute, and the decrease of road accessibility (not included in this research models) may also have played a role in the lack of effect of $\mathrm{T} 3$ operation on real estate prices.

Finally, concerning the general problematic of the impact of a new infrastructure on residential real estate prices, the synthesis of five studies conducted in Île-de-France since 2006 can now forge an opinion answering the recurrent question of the real estate gain induced by public transport. Thus, eight factors were found intervening to change the effects of a new infrastructure on residential real estate prices:

1. New infrastructure type: heavy (metro, RER), light (tramway, bus in dedicated lane);

2. Existence of previous transport supply and level of service of this previous supply;

3. Distances from dwelling to stops (station) and to line;

4. Distinction flat / house (especially on the periphery);

5. Local context (area image and history, social typology, density, dynamism);

6. Lay-out refurbishing during infrastructure construction;

7. General real estate situation trend;

8. Period taken into account before (anticipation) and after (learning effect) operation (short, medium or long term time effects).

The existence of a likely more or less significant real estate gain depends on the crossing of these eight factors. For example, in the case of the T3 as well as the one of the T1 where accessibility gains are low compared with previous situation, the serviced area not thriving and suffering a downgraded image, we proved that there was no significant impact on real estate price two years on, particularly as it occurred during a real estate crisis period. The lay-out refurbishing was not sufficient to change the boulevards image, and many more years will be needed to observe an urban renewal in the area next to the T3. Conversely, at the same time, the extension of the M14 metro line to Olympiades station generated dwelling price increases near the station as compared with not serviced control areas as anticipation and just after the station operation began. In the case of the T2 that serves a corridor with no previous relevant service, even without any particular urban renewal program, there was a real accessibility gain that on its own induced real estate gains in thriving municipalities. In the case of green/quiet neighbourhoods in Paris, it is the environmental gain that triggered slight real estate gains, independently from any accessibility gain or loss dimension. But as in the case of the vicinity of the RER E stations, discrepancies on these gains are large, since each neighbourhood constitutes a specific real estate market the evolution of which strongly depends on the local context. 
However, three invariants are evidenced in those five studies: if real estate gains show up, they differ according to dwelling type (flat/house), they are not induced in the immediate proximity of stations, but beyond 200 metres on average whatever the kind of infrastructure, and it is higher for a heavy mode than for a light mode.

This study finally supports the idea that the recovery of real estate gains cannot be applied in an authoritarian and uniform manner in a pre-designated area around all public transport project stations. All landowner near a new station would be entitled to legally dispute the payment of an additional fixed tax. He/she just needs to request the government to prove that his/her property actually benefited from real estate gains, when scientific studies do not converge on the topic and our conclusions discuss the modulation of the real estate gains according to the aforementioned eight factors. Indeed, the Grand Paris public transport network changed its mind about it. At the very beginning (2008), it forecast to fund itself in significant proportions and in the long run through land and real estate valuation in a 1500 metres radius around new stations. Finally, after the public debate in January 2011, this potential financial source just disappeared from the project-funding scheme. Surely, it was considered as too random and uncertain, thus not likely to be secured. The recognition of scientific studies in this field finally won over system mindset.

At last, it seems necessary to set the means for a genuine suited and designed data collection process of before/after situations, over several years, each time a new transport infrastructure is built, for example by creating specific observatories, if new infrastructure effects on real estate prices are to be actually measured, by making the distinction between pure accessibility gains benefits, and those induced by the urban refurbishing provided with the line creation.

\section{AKNOWLEDGEMENTS}

This research was funded by MEDDTL (Ministry for ecology, sustainable development, transports, and housing) in the framework of PREDIT 4 GO 6 (Programme for research and innovation in land transportation). We thank Yves Crozet, Professor at University of Lyon, President of GO6, and Gérard Brun, from MEDDTL, Secretary general of GO6.

The authors are also grateful to the Paris Notary Chamber for providing us with the geolocated database BIEN. We also thank RATP for data from their tramway OD survey.

Finally, the authors pay tribute to two anonymous referees for their help in improving this paper.

\section{REFERENCES}

Ahamada, I., Flachaire, E. \& Lubat, M. (2007). "Prix des logements et autocorrélation spatiale : une approche semi-paramétrique", Economie Publique, 20, 131-145. 
Armstrong, R. (1994). " Impacts of commuter rail service as reflected in single-family residential property values ", Transportation Research Record, 1466, 88-98.

Beckerich, C. (2000). "Biens publics et valorisation immobilière". Thèse de doctorat en Sciences Economiques, Mention Economie des transports, Faculté de Sciences économiques et de Gestion, Université Lumière Lyon 2.

Benjamin, J.D. \& Sirmans G.S. (1996). "Mass transportation, apartment rent and property values". The Journal of Real Estate Research, 12(1),1-8.

Boarnet, M. G. \& Chalermpong, S. (2001). « New Highways, House Prices, and Urban Development: A Case Study of Toll Roads in Orange County, CA », Housing Policy Debate, 12, 575-605.

Boucq, E. \& Papon, F. (2007). "Assessment of the real estate benefits brought by a light rail infrastructure, quantitative results from a hedonic approach with extensive field data in the Hauts-de-Seine department", Kuhmo Nectar Conference 2007, 9-13 July 2007, Urbino.

Boucq, E. (2008). "Evaluation économique d'une infrastructure de transport en milieu urbain. Le cas du tramway T2 Val de Seine", Thèse de doctorat, Université de Lille I.

Bowes, D.R. \& Ihlanfeldt, K.R. (2001). "Identifying the impacts of rail-transit stations on residential property values". Journal of Urban Economics, 50(1),1-25.

Brossard, T., Joly, D., Tourneux, F.P., Cavailhes, J., Hilal, M., Wavresky, P., Le Gallo, J., Geniaux, G., Napoleone, C., Jayet, H., Ovtracht, N. \& Peguy P.Y. (2007). "La valeur économique des paysages des villes périurbanisées", Économie publique, vol 20, $\mathrm{n}^{\circ} 1, \mathrm{pp} .11-35$.

Calzada, C. \& Decremer, R. (2009). "La ligne à Grande Vitesse Est-européenne : impacts sur les prix immobiliers", INSEE Economie Lorraine, 152.

Cao, X. and Hough, J.A. (2007). "Hedonic Value of Transit Accessibility: An Empirical Analysis in a Small Urban Area, Small Urban \& Rural Transit Center”, Upper Great Plains Transportation Institute, North Dakota State University, research report.

Cavailhès, J. (2005). "Le prix des attributs du logement". Economie et statistique, 381382:91-123.

Cervero, R. \& Kang, D.K. (2011). "Bus rapid transit impacts on land uses and land values in Seoul, Korea", Transport Policy, 18, 102-116.

Cornuel, D., Calcoen, F. \& Leuleu, H. (2003). "Caractéristiques hédoniques et changement environnemental : la couverture de l'A1". Revue d'Economie Régionale et Urbaine 4:597-622.

De Palma, A, Nguyen-Luong, D., Motamedi, K., Ouaras, K. \& Picard, N. (2004 to 2008). "SIMAURIF - Modèle dynamique de simulation de l'interaction Urbanisation Transports en région Île-de-France. Application à la tangentielle nord". Quatre rapports d'étude. Paris, PREDIT-DRAST.

Debrezion, G., Pels, E. \& Rietveld, P. (2007). "The impact of rail transport on real estate prices: An empirical analysis of the Dutch housing market", Working paper, Department of Spatial Economics, VU University Amsterdam.

Deschamps, M. (2008). "Capitalisation immobilière et infrastructures de transport. Une revue critique des méthodes", Revue RTS n¹00

Deymier, G. (2005). "Capitalisation immobilière des gains d'accessibilité : étude de cas sur l'agglomération lyonnaise". Thèse de doctorat en Sciences Economiques, Mention 
Economie des transports, Faculté de Sciences économiques et de Gestion, Université Lumière Lyon 2.

DREIF (2002). "Relations entre infrastructure de transport et prix du foncier et de l'immobilier. Le cas du tramway Saint-Denis - Bobigny", rapport d'étude, 02-02/03, janvier.

Du, H. \& Mulley, C. (2006). "Relationship Between Transport Accessibility and Land Value", Transportation Research Record, 1977, pp. 197-205.

Faburel, G., Maleyre, I. \& Peixotto, F. (2004). « Dépréciation immobilière et ségrégation sociale pour cause de bruit des avions. Mesure économétrique et analyse territoriale dans 8 communes proches de l'aéroport d'Orly ». Université de Paris XII - Institut d'Urbanisme de Paris.

Franklin, J.P. \& Waddell, P. (2003). "A Hedonic Regression of Home Prices in King County, Washington, using Activity-Specific Accessibility Measures”. TRB 2003 Annual Meeting, Washington DC.

Gatzlaff, D.H. \& Smith, M.T. (1993). « The impact of the Miami Metrorail on the Value of Residences Near Station locations », Land Economics, 69, 54-66.

Glachant, M., Bureau, B. \& Nguyen-Luong, D. (2008). "Evaluation quantitative de l'impact des politiques Quartiers verts et Quartiers tranquilles sur les prix de l'immobilier à Paris". PREDIT-ADEME.

Gordon, P. \& Richardson, H.W. (1983). "Intercommunity distribution of tax and land value impacts of air pollution, Urban Ecology, 7, pp. 125-135.

Gravel, N., Trannoy, A. \& Michelangeli, A. (2002). "Measuring the social value of local public goods: a hedonic analysis within Paris Metropolitan Area". Working paper 82, Università Commerciale Luigi Bocconi, Econpubblica, Center for Research on the Public Sector.

Kazmierczak, S. \& Jayet H. (2002). « Tramway Val de Seine, ligne La Défense / Issy-lesMoulineaux et Autoroute A14, La Défense / Orgeval. Exploitation de la base de données CD-Biens et estimation des effets des infrastructures par les fonctions de prix hédonique », pour la Direction Régionale de l'Equipement Île-de-France.

Letombe, G. \& Zuindeau, B. (2001). « L'impact des friches industrielles sur les valeurs immobilières : une application de la méthode des prix hédonistes à l'arrondissement de Lens (Nord Pas de Calais) ». Revue d'Économie Régionale et Urbaine, $n^{\circ}$ 4, pp. 605-624.

Marchand, O. \& Skhiri, E. (1995). "Prix hédoniques et estimation d'un modèle structurel d'offre et de demande de caractéristiques". Economie et Prévision $121: 127-139$.

McDonald, J.F. \& Osuji, C.I. (1995). "The effect of anticipated transportation improvement on residential land values". Regional Science and Urban Economics 25 :261-278.

Nguyen-Luong, D. ( 2006). "Contribution au projet SIMAURIF : Recueil et analyse de données de prix de l'immobilier résidentiel en Île-de-France. Cas du T1 et d'EOLE. Estimation d'un modèle de prix hédonique", IAURIF pour Réseau Ferré de France (RFF).

Ottensmann, J.R., Payton, S. \& Man, J. (2008). “Urban Location and Housing Prices within a Hedonic Model, Journal of Regional Analysis and Policy", 38, pp. 19-35.

Özdilek, U., Des Rosiers, F. \& Canonne, J. (2002). "Les déterminants de la valeur des logements, une approche économétrique sur l'île-de-Montréal". Etudes foncières: 99. 
Prud'homme, R., Koning M. \& Kopp P. (2011) "Substituting a tramway to a bus line in Paris: Costs and benefits" Transport Policy 18(2011) 563-572

Rodríguez, D.A. \& Mojica, C.H. (2009). "Capitalization of BRT network expansions effects into prices of non-expansion areas", Transportation Research Part A, 43, 560-571.

Rosen, S. (1974). "Hedonic prices and implicit markets: product differntiation in pure competition". Journal of Political Economy, 82(1),34-55.

Saulnier, J. (2004). "Une application des prix hédonistes : Influence de la qualité de l'air sur le prix des logements ?", Revue d’Economie Politique, vol. 114, n5, pp.613-636.

Smersh, G.T. \& Smith, M.T. (2000). "Accessibility changes and urban house price appreciation: a constrained optimization approach to determining distance effects". Journal of Housing Economics, 9,187-196.

Tiebout, C. (1956). "A pure theory of local public expenditure" Journal of Political Economy, 64, 416-424.

Yiu, C.Y., Wong, S.K. (2005). "Effects of expected transport improvements on housing prices". Urban Studies,42(1),113-125. 